\title{
CXXII. THE SYNTHESIS OF GLUTAMINE IN PIGEON LIVER
}

\author{
By ÅKE ÖRSTRÖM,' MARGOT ÖRSTRÖM, HANS ADOLF KREBS \\ AND LEONARD VICTOR EGGLESTON
}

From the Department of Biochemistry, University of Sheffield

(Received 1 May 1939)

IT has previously beẹn shown [Edson et al. 1936] that pigeon liver utilizes added $\mathrm{NH}_{3}$ more rapidly than can be accounted for by the rate of hypoxanthine synthesis. Under some conditions, for instance in the presence of 0.02 to $0.04 M$ ammonium pyruvate, the amount of $\mathrm{NH}_{3}$ converted into hypoxanthine is less than $20 \%$ of total $\mathrm{NH}_{3}$ metabolized; the bulk of the $\mathrm{NH}_{3}$ is converted into substances which remained unidentified. We have now identified glutamine in this fraction. Its quantity accounts for about 40 to $50 \%$ of the total $\mathrm{NH}_{3}$ metabolized.

\section{EXPERTMENTAL}

As in the previous experiments slices of pigeon liver suspended in the saline medium of Krebs \& Henseleit [1932] were used. Small scale experiments were carried out in manometric flasks, large scale experiments in "metabolism flasks", as described by Krebs [1933]. These flasks have a diameter of about $11 \mathrm{~cm}$. and they contained not more than $100 \mathrm{ml}$. medium in order to secure sufficient oxygenation. The temperature was $40^{\circ}$. Ammonia was determined according to Parnas \& Heller [1924], amino-N according to Van Slyke [1929] after the removal of $\mathrm{NH}_{3}$ from the solution.

\section{Formation of "amino-nitrogen" in pigeon liver}

Data concerning the rate of $\mathrm{NH}_{3}$ uptake have already been given [Edson et al. 1936] and it has also been mentioned that part of the $\mathrm{NH}_{3}$ is converted into amino compounds. In a series of further experiments we compared the rates of $\mathrm{NH}_{3}$ uptake and of hypoxanthine and "amino- $\mathrm{N}$ " formation. The highest rates of $\mathrm{NH}_{3}$ uptake and amino- $\mathrm{N}$ formation were observed in the presence of pyruvate. An example is given in Table I. In this experiment the amino-N formed accounts for most of the metabolized $\mathrm{NH}_{3}$. "Amino-N", as determined by Van Slyke's method, it should be remembered, does not necessarily imply $=\mathrm{CHNH}_{2}$ groups but would include among other groupings the $-\mathrm{CONH}_{2}$ group of glutamine.

Table I. Utilization of added $\mathrm{NH}_{4} \mathrm{Cl}$ by pigeon liver

The medium contained 0.04 $M$ pyruvate and 0.01 $M \mathrm{NH}_{4} \mathrm{Cl} ; 44 \mathrm{mg}$. liver; $2 \mathrm{hr}$.; $40^{\circ}$.

$\begin{array}{ll}\text { mg. } \mathrm{NH}_{3}-\mathrm{N} \text { added } & 0.840 \\ \text { mg. } \mathrm{NH}_{3}-\mathrm{N} \text { used } & 0.795 \\ \text { mg. hypoxanthine-N formed } & 0.110 \\ \text { mg. "amino-N" } & 0.658\end{array}$

Data for control to which no $\mathrm{NH}_{4} \mathrm{Cl}$ was added calculated for same quantity of tissue.

$\begin{array}{ll}\text { mg. } \mathrm{NH}_{3}-\mathrm{N} \text { formed } & 0.021 \\ \mathrm{mg} \text {. hypoxanthine-N formed } & 0.081 \\ \mathrm{mg} \text {. amino- } \mathrm{N} \text { formed } & 0.163\end{array}$

1 Rockefeller Travelling Research Fellow. 


\section{Formation of amide-nitrogen}

If the solution from which $\mathrm{NH}_{3}$ has been removed by pigeon liver is heated for $10 \mathrm{~min}$. to $100^{\circ}$ in the presence of $5 \% \mathrm{H}_{2} \mathrm{SO}_{4}$, 15 to $25 \%$ of the $\mathrm{NH}_{3}$ metabolized returns to the solution. Examples are given in Table II. Heating for

Table II. $\mathrm{NH}_{3}$-consumption and amide formation in pigeon liver

\begin{tabular}{|c|c|c|c|c|c|c|c|}
\hline No. & $\begin{array}{l}\text { Substrate added (total volume of } \\
\text { medium } 3-4 \mathrm{ml} \text {.) }\end{array}$ & mg. tissue & $\begin{array}{l}\text { Time } \\
\text { min. }\end{array}$ & $\begin{array}{l}\mu \text { l. } \mathrm{NH}_{3} \\
\text { used }\end{array}$ & $\begin{array}{l}\mu \text { l. amide- } \\
\mathrm{N} \text { formed }\end{array}$ & $Q_{\mathrm{NH} 3}$ & $Q_{\text {amide-N }}$ \\
\hline 1 & $\begin{array}{l}0.01 \quad M \mathrm{NH}_{4} \mathrm{Cl} ; 0.04 M \text { pyruvate } \\
0.01 M \mathrm{NH}_{4} \mathrm{Cl} ; 0.02 M M(+) \text { glutamate } \\
0.01 M \mathrm{NH}_{4} \mathrm{Cl} ; 0.01 M \text {-ketoglutarate }\end{array}$ & $\begin{array}{l}29 \cdot 9 \\
29 \cdot 6 \\
40 \cdot 2 \\
36 \cdot 0\end{array}$ & $\begin{array}{l}90 \\
90 \\
90 \\
90\end{array}$ & $\begin{array}{l}+26 \\
-792 \\
-412 \\
-447\end{array}$ & $\begin{array}{l}39 \cdot 6 \\
131 \\
115 \\
113\end{array}$ & $\begin{array}{l}+0 \cdot 58 \\
-17 \cdot 9 \\
-6 \cdot 8 \\
-8 \cdot 3\end{array}$ & $\begin{array}{l}+0 \cdot 88 \\
+2 \cdot 95 \\
+1 \cdot 91 \\
+2 \cdot 09\end{array}$ \\
\hline 2 & $\begin{array}{l}0.0066 M \mathrm{NH}_{4} \mathrm{Cl} \\
0.0066 M \mathrm{NH}_{4} \mathrm{Cl} ; 0.02 M \text { pyruvate } \\
0.0066 M \mathrm{NH}_{4} \mathrm{Cl} ; 0.02 M \text { oxaloacetate }\end{array}$ & $\begin{array}{l}16 \cdot 1 \\
13 \cdot 0 \\
10 \cdot 9\end{array}$ & $\begin{array}{l}60 \\
60 \\
60\end{array}$ & $\begin{array}{l}-118 \\
-267 \\
-186\end{array}$ & $\begin{array}{l}30 \\
42 \cdot 5 \\
31 \cdot 7\end{array}$ & $\begin{array}{l}-7 \cdot 35 \\
-20 \cdot 5 \\
-17 \cdot 1\end{array}$ & $\begin{array}{l}+1 \cdot 87 \\
+3 \cdot 28 \\
+2 \cdot 92\end{array}$ \\
\hline 3 & $\begin{array}{l}0.01 M \mathrm{NH}_{4} \mathrm{Cl} \\
0.01 M \mathrm{NH}_{4} \mathrm{Cl} ; 0.02 M \alpha \text {-ketoglutarate } \\
0.01 M \mathrm{NH}_{4} \mathrm{Cl} ; 0.02 M l(+) \text { glutamate } \\
0.01 M \mathrm{NH}_{4} \mathrm{Cl} ; 0.02 M \text { pyruvate }\end{array}$ & $\begin{array}{l}32 \cdot 5 \\
30 \cdot 7 \\
27 \cdot 8 \\
28 \cdot 7\end{array}$ & $\begin{array}{l}90 \\
90 \\
90 \\
90\end{array}$ & $\begin{array}{l}-304 \\
-327 \\
-266 \\
-618\end{array}$ & $\begin{array}{l}-76 \cdot 5 \\
100 \\
85 \cdot 5 \\
145\end{array}$ & $\begin{array}{l}-6 \cdot 25 \\
-7 \cdot 1 \\
-6 \cdot 4 \\
-14 \cdot 4\end{array}$ & $\begin{array}{l}+1 \cdot 57 \\
+2 \cdot 17 \\
+2 \cdot 05 \\
+3 \cdot 37\end{array}$ \\
\hline 4 & $\begin{array}{l}0.02 M \mathrm{NH}_{4} \mathrm{Cl} \\
0.02 M \mathrm{NH}_{4} \mathrm{Cl} ; 0.02 M \text { pyruvate } \\
0.02 M \mathrm{NH}_{4} \mathrm{Cl} ; 0.02 M \text { oxaloacetate }\end{array}$ & $\begin{array}{l}68 \cdot 7 \\
73 \cdot 2 \\
61 \cdot 0\end{array}$ & $\begin{array}{l}120 \\
120 \\
120\end{array}$ & $\begin{array}{l}-182 \\
-1070 \\
-800\end{array}$ & $\begin{array}{r}98 \\
198 \\
157\end{array}$ & $\begin{array}{l}-1 \cdot 3 \\
=7 \cdot 3 \\
-6 \cdot 6\end{array}$ & $\begin{array}{l}+0 \cdot 71 \\
+1 \cdot 35 \\
+1 \cdot 28\end{array}$ \\
\hline 5 & $\begin{array}{l}0.02 M \mathrm{NH}_{4} \mathrm{Cl} \\
0.02 M \mathrm{NH}_{4} \mathrm{Cl} ; 0.02 M \text { pyruvate } \\
0.02 M \mathrm{NH}_{4} \mathrm{Cl} ; 0.04 M \text { pyruvate } \\
0.02 M \mathrm{NH}_{4} \mathrm{Cl} ; 0.04 M l \text { ( ) lactate } \\
0.02 M \mathrm{NH}_{4} \mathrm{Cl} ; 0.04 M l \text { +)glutamate } \\
0.02 M \mathrm{NH}_{4} \mathrm{Cl} ; 0.04 M \alpha \text {-ketoglutarate }\end{array}$ & $\begin{array}{l}52 \cdot 5 \\
38 \cdot 4 \\
37 \cdot 3 \\
47 \cdot 6 \\
42 \cdot 0 \\
44 \cdot 0\end{array}$ & $\begin{array}{l}100 \\
100 \\
100 \\
100 \\
100 \\
100\end{array}$ & $\begin{array}{l}-658 \\
-1090 \\
-1122 \\
-419 \\
-589 \\
-574\end{array}$ & $\begin{array}{l}144 \\
257 \\
313 \\
146 \\
248 \\
148\end{array}$ & $\begin{array}{l}-7 \cdot 5 \\
-17 \cdot 0 \\
-18 \cdot 1 \\
-5 \cdot 4 \\
-8 \cdot 4 \\
-7 \cdot 0\end{array}$ & $\begin{array}{l}+1 \cdot 6 \\
+4 \cdot 0 \\
+5 \cdot 0 \\
+1 \cdot 84 \\
+3 \cdot 55 \\
+2 \cdot 28\end{array}$ \\
\hline
\end{tabular}

more than $10 \mathrm{~min}$. does not significantly increase the yield of $\mathrm{NH}_{3}$. Alkaline hydrolysis (10 min., $100^{\circ}, 2 \mathrm{~N} \mathrm{NaOH}$ ) liberates the same quantity of $\mathrm{NH}_{3}$ as acid hydrolysis. The solutions thus contain a compound which behaves like glutamine or similar acid amides [vide Krebs, 1935, 1].

The yield of amide- $\mathrm{N}$ is greatest in the presence of pyruvate. There is only a small increase over the blank when $l(+)$ glutamate or $\alpha$-ketoglutarate is added. In this respect pigeon liver behaves differently from a group of tissues comprizing mammalian brain and retina and the kidney of guinea-pig and rabbit in which a synthesis of glutamine was previously found to take place [Krebs, 1935]. In these tissues a rapid synthesis of glutamine occurs if ammonium glutamate is added. Ammonium pyruvate (and alanine) are also converted into glutamine but the rate of the synthesis is in this case no more than 10 or $20 \%$ of that observed in the presence of ammonium glutamate (Table III).

Table III. Formation of glutamine in guinea-pig kidney

$\begin{array}{cc}40^{\circ} \text {; bicarbonate saline; } 0.01 M \mathrm{NH}_{4} \mathrm{Cl} .5 \% \mathrm{CO}_{2} \text { in } \mathrm{O}_{2} . \\ \text { Substrates (final concentration) } & Q_{\text {amide.N }} \\ & 1 \cdot 31 \\ 0.02 M \text { pyruvate } & 2 \cdot 40 \\ 0.02 M l(+) \text { glutamate } & 12 \cdot 9 \\ 0.02 M l(+ \text { )alanine } & 4 \cdot 7 \\ 0.03 M \alpha \text {-ketoglutarate } & 3 \cdot 6 \\ 0.02 M \text {-ketoglutarate; } 0.02 M I(+) \text { alanine } & 10 \cdot 3\end{array}$

\section{Isolation of the acid amide}

The determination of amide- $\mathrm{N}$ on samples containing $0 \cdot 05-0 \cdot 1 \mathrm{mg}$. amide- $\mathrm{N}$ proved a convenient guide in the isolation of the amide. The amide compound is not precipitated by phosphotungstic acid, $\mathrm{Cu}$ or $\mathrm{Ag}$ salts, but forms an 
insoluble compound with mercuric salts in weakly acid, neutral or weakly alkaline solution. After many preliminary tests the isolation was finally carried out in the following way.

Two or three livers of well fed, freshly killed pigeons are roughly weighed and then sliced with a razor. For each g. fresh weight $7 \mathrm{ml}$. saline [Krebs \& Henseleit, 1932], $0 \cdot 7 \mathrm{ml} .0 \cdot 2 M \mathrm{NH}_{4} \mathrm{Cl}$ and $1 \cdot 4 \mathrm{ml} .0 \cdot 2 M$ sodium pyruvate are measured into a metabolism flask [Krebs, 1933]. The proportion of $\mathrm{NH}_{4} \mathrm{Cl}$ to tissue chosen allows an almost complete utilization of the added $\mathrm{NH}_{3}$ during an experimental period of $3 \mathrm{hr}$. The removal of $\mathrm{NH}_{3}$ simplifies the purification of the substance.

The flasks are filled with $5 \% \mathrm{CO}_{2}$ in $\mathrm{O}_{2}$ and shaken at $40^{\circ}$ for $3 \mathrm{hr}$. at the rate of 40-60 periods per min. After shaking 0.2 vol. $30 \%$ trichloroacetic acid is added and the mixture is cooled in ice. It is filtered after about $30 \mathrm{~min}$. A slight turbidity of the filtrate does not interfere with the later stages of the isolation and may be neglected. The filter is washed with $3 \%$ trichloroacetic acid.

The acid amide is then precipitated with the mercuric nitrate reagent introduced by Schulze [1882]. To each $50 \mathrm{ml}$. of the combined filtrate and washings are added $5 \mathrm{ml}$. of mercuric oxide, dissolved in nitric acid $(160 \mathrm{ml}$. concentrated $\mathrm{HNO}_{3}, 300 \mathrm{ml} . \mathrm{H}_{2} \mathrm{O}$ and $220 \mathrm{~g}$. $\mathrm{HgO}$ are boiled under reflux until the oxide is dissolved. After cooling $N \mathrm{NaOH}$ is added to produce a faint opalescence. The volume is made up to 1 l. with $\mathrm{H}_{2} \mathrm{O}$ ).

A $30 \% \mathrm{NaOH}$ solution is slowly added under constant shaking until the solution is distinctly alkaline (litmus). It is then placed in the refrigerator overnight. The precipitate is centrifuged and the supernatant is tested with a drop of $\mathrm{NaOH}$. If a yellow precipitate is formed more $\mathrm{NaOH}$ is added. The precipitate which contains among other substances the mercury salts of the "amide" is washed twice on the centrifuge with distilled water. After the last washing the precipitate is suspended in water and treated with $\mathrm{H}_{2} \mathrm{~S}$. The mercuric sulphide is filtered off and washed with water. The filtrate is concentrated in vacuo to about 2 or $3 \mathrm{ml}$, transferred into a centrifuge tube and dried in a vacuum desiccator.

The oily or dry residue is stirred with about $0.5 \mathrm{ml}$. water, $0.1 \mathrm{ml}$. conc. $\mathrm{HCl}$ and $3 \mathrm{ml}$. methyl alcohol; if an insoluble fraction remains, it is removed by centrifuging; the supernatant is mixed with sufficient ether to produce a turbidity. Crystals appear soon when the mixture is placed in the ice box. Addition of more ether increases the yield, but sometimes lowers the purity of the product. Yield: $30-50 \mathrm{mg}$. per $10 \mathrm{~g}$. wet liver. The substance is recrystallized by dissolving it in a few drops of water, adding 4 vol. methyl alcohol and ether as described above.

The combined yields from several experiments were recrystallized until the melting point remained constant at $171-173^{\circ}$ (uncorrected). The compound begins to darken a few degrees below this temperature and decomposes when melting. The analytical data (Dr Weiler and Dr Strauss) agree with those for glutamine hydrochloride $\left(\mathrm{C}_{5} \mathrm{H}_{11} \mathrm{~N}_{2} \mathrm{O}_{3} \mathrm{Cl}\right)$ :

$$
\begin{aligned}
& \text { C found : } 32.91 \% ; 33.05 \% \text {; calculated for } \mathrm{C}_{5} \mathrm{H}_{11} \mathrm{~N}_{2} \mathrm{O}_{3} \mathrm{Cl}: 32.86 \%
\end{aligned}
$$

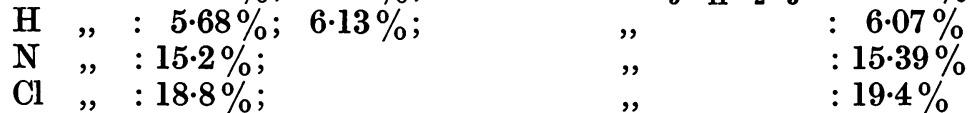

Treatment with chloramine $\mathrm{T}$ under the conditions described by Cohen [1939] for the determination of glutamic acid yielded succinic acid. From $2 \cdot 87 \mathrm{mg}$. of 
the substance $1 \cdot 1 \mathrm{mg}$. succinic acid were obtained. The yield is not quantitative but of the same order as that obtained with pure glutamine $(60-70 \%)$.

A preparation of glutamine hydrochloride obtained by dissolving glutamine from mangel-wurzels in a small volume of $10 \% \mathrm{HCl}$ and precipitation with alcohol-ether was identical in every respect with the substance isolated from pigeon liver. The mixed melting points were unchanged.

The quantities of glutamine isolated in the pure state varied from 40 to $60 \%$ of the total "amide" present in the starting material. A considerable loss during the preparation is almost unavoidable owing to the instability of glutamine, and we therefore assume that glutamine represents most, if not all, of the amide synthesized in pigeon liver.

\section{Glutamine synthesis in other species}

Fowl and duck livers also form glutamine from added ammonium pyruvate and the rate was found to be about the same as in pigeon liver. Since the isolation of glutamine was carried out in the same way, these experiments are not described in full.

Rat liver, too, produces an acid amide, but in this case the rate is not appreciably increased over the blank when ammonium pyruvate is added. The maximum rate observed in rat liver was $1 \cdot 0-1 \cdot 5\left(Q_{\text {amide- }}\right)$, against values up to 5.0 in pigeon liver. The amide formed in rat liver has not yet been isolated and identified.

\section{Discussion}

Synthesis of glutamine from 3-carbon compounds. The synthesis of glutamine from ammonium pyruvate involves the formation of a 5-carbon chain. It is probable that the synthesis of $\alpha$-ketoglutaric acid is the primary step in the formation of glutamine. Several mechanisms have previously been discussed for the synthesis of this compound [vide Krebs, 1935, 2; Weil-Malherbe, 1936; Krebs \& Johnson, 1937] but it is yet too early to decide between the various possibilities.

Glutamine synthesis in guinea-pig kidney and bird's liver. It was pointed out that guinea-pig kidney. (and some other tissues) synthesize glutamine more rapidly from ammonium glutamate than from ammonium pyruvate, whilst pigeon liver yields glutamine more rapidly when ammonium pyruvate is the substrate. Such differences in rates, in our view, do not necessarily indicate entirely different mechanisms; they may be explained on the assumption that the factors limiting the rate of glutamine synthesis are, different in the two groups of tissues.

Significance of the glutamine synthesis. The significance of the synthesis of glutamine remains obscure as long as the role of glutamine in tissue metabolism is unknown. Some observations mentioned in the discussion of the preceding paper and the facts reported in this paper leave no doubt that glutamine is a factor of general importance in cell metabolism, but the nature of its function is not yet clear.

\section{SUMMARY}

Slices of pigeon, fowl or duck liver form glutamine from ammonium pyruvate. The substance was isolated as glutamine hydrochloride; 1 g. of liver (dry weight) produces up to $30 \mathrm{mg}$. glutamine per hour.

The authors gratefully acknowledge the assistance of the Rockefeller Foundation and of the Medical Research Council. 


\section{REFERENCES}

Cohen (1939). Biochem. J. 33, 551.

Edson, Krebs \& Model (1936). Biochem. J. 30, 1380.

Krebs (1933). Hoppe-Seyl. Z. 217, 191.

- $(1935,1)$. Biochem. J. 29, 1951.

(1935, 2). Nature, Lond., 138, 288.

_ \& Henseleit (1932). Hoppe-Seyl. Z. 210, 33.

—_ \& Johnson (1937). Enzymologia, 4, 148.

Parnas \& Heller (1924). Biochem. Z. 152, 1.

Schulze (1882). Ber. dtsch. chem. Ges. 15, 2855.

Van Slyke (1929). J. biol. Chem. 83, 425.

Weil-Malherbe (1936). Biochem. J. 30, 665 and Nature, Lond., 138, 551. 